\title{
Nomenclature of Bacteria in Leaf Nodules of the Families Myrsinaceae and Rubiaceae
}

\author{
HARRY T. HORNER, JR., and NELS R. LERSTEN
}

Department of Botany and Plant Pathology, Iowa State University, Ames, Iowa 50010

\begin{abstract}
Species of eight bacterial genera have been proposed in the literature as leaf-nodule symbionts: Mycobacterium, Bacillus, Bacterium, Rhizobium, Chromobacterium, Phyllobacterium, Klebsiella, and Xanthomonas. The first four are discounted either by rules of nomenclature (i.e., Bacterium) or because modern generic limits exclude the nodule species originally placed in them. Species of the latter four genera have been isolated recently by several investigators. Even though some of these investigators favor the hypothesis of one bacterial symbiont in all leaf-nodulated plants, all four genera must still be considered as containing legitimate symbionts. Phyllobacterium foliicola (Miehe) comb. nov. is proposed as the legitimate name of the type species of Phyllobacterium Knösel to replace the illegitimate name $P$. myrsinacearum Knösel.
\end{abstract}

Symbiotic bacteria have been reported to inhabit nodules within leaves of about 400 species in two unrelated dicotyledonous plant families, Myrsinaceae and Rubiaceae (14). In contrast, only six species from three genera have been studied anatomically and bacteriologically to verify this relationship.

There are numerous bacteria which some investigators believe inhabit various other aerial structures of plants such as leaf invaginations are considered casual associations in that the (e.g., glands, trichomes, and nectaries). These are considered casual associations in that the bacteria are not passed on from one generation to the next, nor is there any mutualism involved.

Bacterial leaf nodules are here defined as internal cavities in the leaf lamina, open to the exterior by way of stomatal pores only in early stages of nodule development. The bacteria inhabiting such nodules are part of a population maintained by the host plant in the vegetative and floral buds and passed to succeeding generations through the seeds.

On the basis of this definition, leaf nodules are presently recognized only in three genera, Ardisia of the Myrsinaceae, and Pavetta and Psychotria of the Rubiaceae. Members of three other families with distinct bacterial associations are excluded because they do not correspond to our definition of nodules: Dioscorea [Dioscoreaceae (23)], Cassia [Leguminosae (24)], and Cienfugosia [Malvaceae (13)]. Bac- terial symbioses also have been reported from several other families in which bacteria are associated with glands (14). In this paper, the literature pertaining to the nomenclature of leaf-nodule bacteria is reviewed.

\section{RESULTS AND DISCUSSION}

Previous workers have identified bacteria within leaf nodules and buds and seeds of nodulated plants; the isolations have been typically successful from buds and seeds, but only occasionally from nodules. The isolation and identification of nodule bacteria were done initially by Miehe (17) and von Faber (26), who established the cyclic nature of the symbiosis. Various investigators have tried to satisfy Koch's postulates by reinfecting nodule-free plants ("cripples") with isolates. Cripples can develop spontaneously from certain seeds of a batch upon germination or are induced from seeds heat-treated to kill the enclosed bacteria but not the embryos (Y. M. Centifanto, Ph.D. thesis, Univ. of Florida, Gainesville, 1964; P. De Jongh, Ph.D. thesis, Univ. of Leyden, Holland, 1938; references 5, 6, 20, and 27). Adjanohoun (1), using a Psychotria species with elongate nodules flanking the major veins, tried to induce nodules in other parts of the leaf blade. The results in his experiments and in those of other researchers, except for those of Miehe (20), were reported to be positive. 
However, in none of these cases was the organism re-isolated and compared to the original isolate.

Bettelheim, Gordon, and Taylor (2) used a fluorescent-antibody technique to identify and establish that their cultured isolates from seeds of Ardisia crispa and Psychotria nairobiensis also occurred in leaf nodules and other tissues of eight other nodulated species of both families. They regarded the use of cripples for reinfection experiments as invalid because, "... no precautions were taken against adventitious infections, nor was it appreciated that such plants might revert to normal."

Organisms belonging to eight bacterial genera have been isolated from leaf nodules on the basis of putative pure cultures: Mycobacterium, Bacillus, Bacterium, Xanthomonas, Rhizobium, Klebsiella, Chromobacterium, and a new genus, Phyllobacterium. Table 1 summarizes the nomenclatural history.

Myrsinaceae. Miehe (17), the first to describe a leaf-nodule bacterium from Ardisia crispa, pointed out the cyclic nature of the symbiosis within the plant (based on anatomical studies) and clearly outlined the differences between leaf-nodule and root-nodule bacteria. He described the bacterium only in the host plant under the name Bacterium foliicola. Miehe (18) later characterized the bacterium in pure culture and changed the name to Bacillus foliicola, using this name consistently in his later papers $(19,20)$. He was never able to successfully reinoculate crippled plants (20). He did compare his isolate to von Faber's (26) Pavetta isolate (Mycobacterium rubiacearum; see Rubiaceae section below), noting several differences and suggesting that this latter bacterium might better be called Bacterium rubiacearum. Miehe (18) also isolated another bacterium which he named Bacterium repens and which he considered a constant companion of Bacillus folicola; the former was not regarded by Miehe as the nodule bacterium.

P. De Jongh (Ph.D. thesis, Univ. of Leyden, Holland, 1938; reference 6) repeated most of Miehe's (17-20) work. He described the organism under the name Bacterium foliicola (Miehe) De Jongh, basing the change of genus on the use in Bergey's Manual (4th ed.) of Bacillus for spore-forming, aerobic bacteria. De Jongh overlooked the original use of Bacterium foliicola by Miehe (17), as Ziegler (29) pointed out.

De Vries and Derx (8) isolated a bacterium from species of three genera (including Ardisia crispa) and named it Mycoplana rubra (den Dooren de Jongh) de Vries and Derx. Further isolations by them of the same organism from non-nodulated species, soil and river water led them to conclude that $M$. rubra was not the nodule bacterium but its companion.

In 1954, Hanada (10) isolated what he called a symbiotic bacterium from Ardisia hortorum. He compared his organism with the characteristics listed for Bacillus foliicola Miehe and Mycobacterium rubiacearum von Faber and found his organism to be different, naming it Xanthomonas hortoricola. Bose (4) isolated, but did not name, a bacterium he obtained from Ardisia humilis. He merely said it appeared to be a Bacillus-type L-form. Ziegler (29) isolated bacteria from both Ardisia crispa and Pavetta zimmermanniana and concluded from culture characteristics and electron microscope observations that the two isolates belonged to different species. He suggested that Miehe's Bacillus foliicola revert to Bacterium foliicola [according to Miehe (17)] and that von Faber's Mycobacterium rubiacearum be renamed Bacterium rubiacearum (von Faber) Miehe.

Knösel (13) dealt with a number of species in the families Rhizobiaceae and Pseudomonadaceae in relation to star-forming ability in culture. For bacteria isolated from Ardisia crispa and $A$. crenata, he created a new genus, Phyllobacterium, solely for leaf-nodule bacteria, with $P$. myrsinacearum (Miehe) Knösel as the type species. However, Knösel cited Bacterium foliicola Miehe 1911 as a synonym of "Phyllobacterium myrsinacearum (Miehe)," and it is obvious that he rejected the specific epithet folicola in favor of myrsinacearum. P. myrsinacearum is therefore an illegitimate combination because the earliest available specific epithet was not used. The correct name for the type species of Phyllobacterium Knösel is $P$. foliicola (basionym: Bacterium foliicola Miehe), which we here propose as a new combination. Later workers have failed to cite Knösel, except Kern (12), who isolated bacteria from two leaf-nodulated species of Ardisia and called them Phyllobacterium myrsinacearum (13) without characterizing them himself.

J. F. Gordon (Ph.D. thesis, Imperial College, London, England, 1963) reviewed the earlier work on leaf-nodule bacteria, concluding that the identity and biological significance of the symbiotic bacteria were still in doubt. With a bacterium isolated from seeds, he circumvented Koch's postulates by employing the antigen-antibody technique to show that his isolate occurred in 10 nodulated species from the families Myrsinaceae and Rubiaceae. No antibody reaction occurred with an unnodulated 


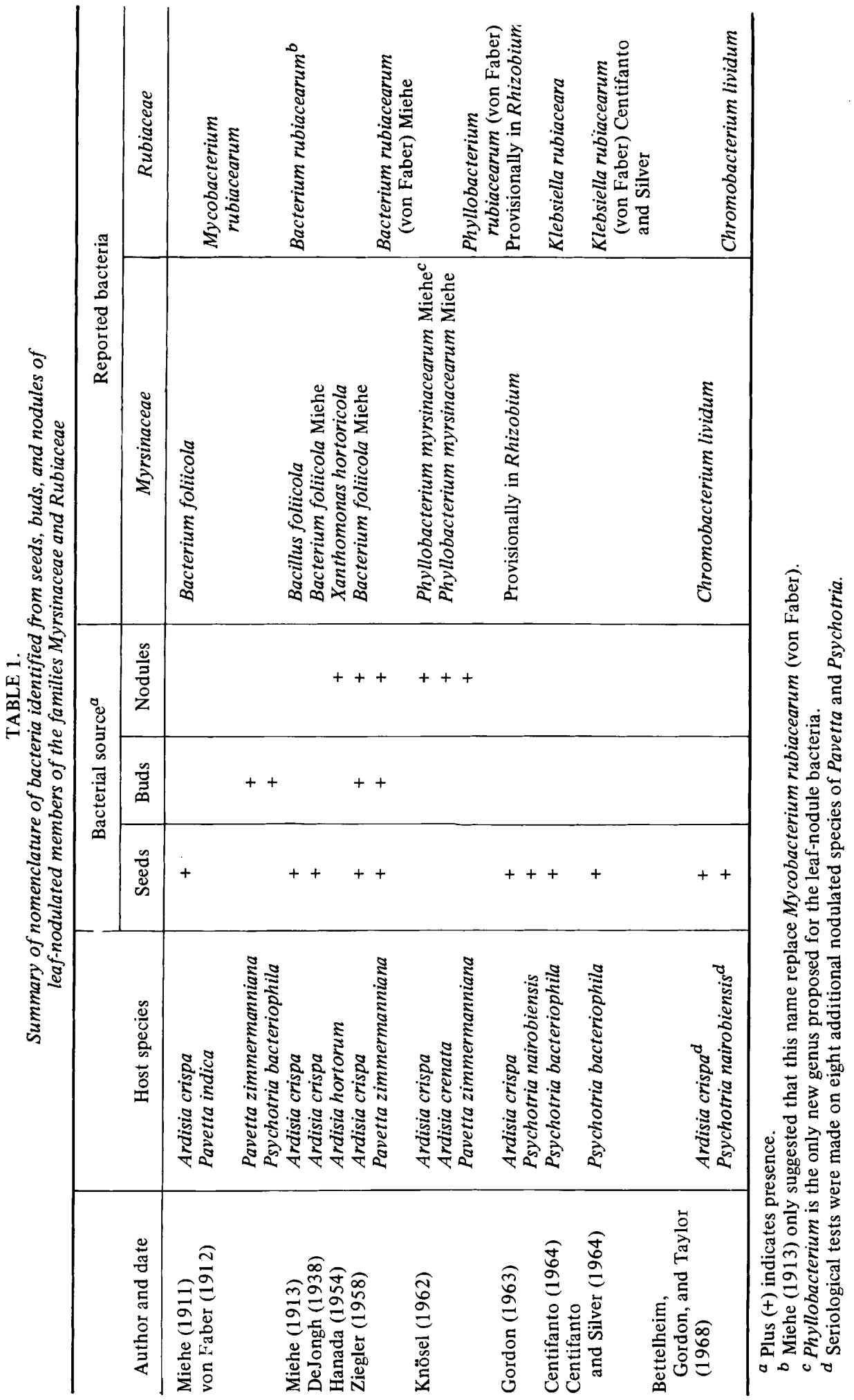


species. Gordon provisionally placed his organism in the genus Rhizobium. Additional occasional isolates from the seeds, which Gordon called contaminants, were identified by him as Mycoplana rubra, Xanthomonas sp., Aerobacter sp., Erwinia or Pectobacterium sp., Aeromonas sp., and Pseudomonas sp.

In a later publication by Bettelheim, Gordon, and Taylor (2), much of the information presented by Gordon was used; in addition, they elaborated on the cultural characteristics of the isolate and compared it to known reference cultures. They concluded that their bacterium belonged to Chromobacterium lividum and that it be considered the leaf-nodule symbiont of both plant families.

Rubiaceae. Zimmermann (30) showed anatomically that the nodules of four Pavetta species contained bacteria, as did Boas (3) in two species of Psychotria. Neither isolated nor named the bacteria.

Von Faber (26) investigated the symbiosis in Pavetta and Psychotria and, like Miehe (17), pointed out the cyclic nature of the bacteria within the plants. He regarded his isolate as a new species and named it Mycobacterium rubiacearum. Von Faber (27) reintroduced the isolate into crippled plants and showed that it was the symbiont. As stated previously, Miehe (18) suggested that von Faber's isolate should be named Bacterium rubiacearum.

Georgevitch (9) and Rao (22) isolated bacteria from Kraussia (Psychotria) and Pavetta species, respectively. Neither one named his isolate, but each gave a few characteristics. De Vries and Derx (8) gave the name Mycoplana rubra to the companion of the nodule-bacterium they consistently isolated from various sources, including nodulated species of Pavetta and Psychotria. Adjanohoun (1) isolated a bacterium from Psychotria calva and said it had certain "flavobacterium-like" characteristics. No specific name was given, however. Ziegler (29) compared his isolate from Pavetta zimmermanniana with von Faber's Mycobacterium rubiacearum and used the name Bacterium rubiacearum (von Faber) Miehe.

The treatment of Phyllobacterium by Knösel (13) included a description of the cultured bacteria from Pavetta zimmermanniana. Knösel retained the specific epithet of von Faber (26) and listed the Pavetta symbiont as Phyllobacterium rubiacearum (von Faber) Knösel. Kern (12) isolated bacteria from three Psychotria species and one Pavetta species and called all the isolates Phyllobacterium rubiacearum (13) without characterizing them himself.

J. F. Gordon (Ph.D. thesis, Imperial College,
London, England, 1963), using Pavetta and Psychotria species to show that his seed isolate also occurs in the leaves and buds, provisionally placed his organism in Rhizobium.

Silver, Centifanto, and Nicholas (25) isolated a bacterium from a Psychotria species and reported it to be a Klebsiella species. Y. M. Centifanto, in an unpublished thesis (Univ. of Florida, Gainesville, 1964), named it Klebsiella rubiaceara. Centifanto and Silver (5) gave the culture characteristics of the latter organism and named it Klebsiella rubiacearum (von Faber) Centifanto and Silver. They reinfected cripples of Psychotria bacteriophila $\quad(=P$. punctata) with their isolate and reportedly obtained normal-looking nodules within two weeks. Isolates of Klebsiella rubiacearum were obtained directly from Silver and were used in later studies dealing with serology and deoxyribonucleic acid (DNA) base ratios $(7,16,21)$; they were shown to be Klebsiella pneumoniae. It should be pointed out that these isolates were not derived from the type strain $(K$. rubiacearum ATCC 15574). Kern (12) carried out a variety of DNA hybridizations among various isolates of Agrobacterium and Rhizobium species, Phyllobacterium myrsinacearum, P. rubiacearum, and the type strain of Klebsiella rubiacearum (ATCC 15574) (25). Using Agrobacterium tumefaciens 147 as the DNA source, he found that the range of per cent DNA hybridization was 19.2 to 39.0 for the Agrobacterium isclates, 9.5 to 30.0 for the Rhizobium isolates, 20.7 to 27.7 for Phyllobacterium rubiacearum, 8.4 to 11.3 for P. myrsinacearum, and only 4.8 for Klebsiella rubiacearum. These last results lend support to the previous indications $(7,16,21)$ that $K$. rubiacearum is not the leaf-nodule symbiont. Furthermore, Kern (12) carried out ferritinantibody reactions developing antisera from cultured bacteria from Psychotria bacteriophila and what he called $P$. maingay $i$ (misidentified, since this species is known not to contain leaf nodules). He tested freshly isolated bacteria from leaf nodules and got positive results. However, he never made in situ tests.

Bettelheim, Gordon, and Taylor (2), with bacteria from Psychotria nairobiensis seeds, showed serologically that their isolate, which they called Chromobacterium lividum, existed in nodules and other tissues of 10 species from both families.

Lersten and Horner (15), Horner and Lersten (11), and Whitmoyer and Horner (28), with light and electron microscopy, showed the bacteria in the nodules and shoot apical regions of Psychotria bacteriophila $(=P$. punctata), as 
did Kern (12). Lersten and Horner (15) mentioned that their organism, although not successfully cultured, resembled morphologically that of Centifanto and Silver (5).

After more than a half century of sporadic investigations, the status of the leaf-nodule bacteria is still uncertain. Of the eight bacterial genera mentioned in the literature as being associated with leaf nodules, four can be discarded: Bacterium is disallowed by the rules of nomenclature, Rhizobium by its generic definition, Bacillus by Opinion 4, which excludes non-endospore-forming bacteria, and Mycobacterium because it excludes gram-negative bacteria. Of the four remaining genera, Xanthomonas comprises 60 species, most of which are considered plant pathogens affecting various aerial organs of both monocots and dicots. None have been described from members of either the Myrsinaceae or Rubiaceae. Klebsiella rubiacearum has been studied by various workers using DNA base ratio and hybridization techniques and has been reported to be identical to $K$. pneumoniae. Kern (12) carried out serological tests on several taxa, including his own bacterial isolates of several leaf-nodulated species and $K$. rubiacearum ATCC 15574. His findings reinforce the previous results and, therefore, cast some doubt on whether K. rubiacearum is in fact the leaf-nodule symbiont.

The two remaining genera, Phyllobacterium and Chromobacterium, are better documented as containing leaf organisms. Knösel (13) specifically created Phyllobacterium (family Rhizobiaceae) for leaf-nodule bacteria which he isolated and characterized from nodules of both plant families. Chromobacterium, also in the family Rhizobiaceae, contains common soil and plant organisms, which by serological methods have been detected in various aerial structures of nodulated plants.

On the basis of the works cited above, the strongest evidence suggests that Phyllobacterium and especially Chromobacterium may be the true leaf-nodule bacteria. The choice of Chromobacterium lividum as the sole symbiont as determined by the antigen-antibody technique of Bettelheim, Gordon, and Taylor (2), however, will have to be assessed by other studies, since the identification of the bacteria involved will have far-reaching implications regarding all aspects of leaf-nodule symbiosis. For these reasons, and because of the need to reinvestigate the results presented for Xanthomonas and Klebsiella, the following organisms should, for the present, be considered as possible leaf-nodule bacteria: Chromobacterium lividum, Phyllobacterium foliicola, P. rubiacearum, Xanthomonas hortoricola, and Klebsiella rubiacearum.

\section{ACKNOWLEDGMENTS}

This paper was supported by Iowa State University through a Faculty Improvement Leave to N. R. L. and by National Science Foundation grant GB-30801 to N. R. L.

The authors would like to thank R. E. Buchanan and J. G. Holt for their interest and encouragement. We also wish to thank Sandy Blake for typing the manuscript.

\section{LITERATURE CITED}

1. Adjanohoun, M. E. 1957. Etude cytologique et genése des galles bactérienes des Rubiacées africaines du genre Psychotria. C. R. H. Acad. Sci. 245:576-578.

2. Bettelheim, K. A., J. F. Gordon, and J. Taylor. 1968. The detection of a strain of Chromobacterium lividum in the tissues of certain leaf-nodulated plants by the immunofluorescence technique. J. Gen. Microbiol. 54:117-184.

3. Boas, F. 1911. Zwei neue Vorkommen von Bakterienknoten in Blättern von Rubiaceen. Ber. Deut. Bot. Ges. 29:416-418.

4. Bose, S. R. 1955. Hereditary (seed-borne) symbiosis in Ardisia humilis Vahl. Nature (London) 175: 395 .

5. Centifanto, Y. M., and W. S. Silver. 1964. Leaf-nodule symbiosis. I. Endophyte of Psychotria bacteriophila. J. Bacteriol. 88: 776-781.

6. De Jongh, P. 1938. On the symbiosis of Ardisia crispa (Thunb.) A. DC. Verh. Kon. Ned. Akad. Wetensch. Afd. Natuurk. Tweede Sect. II 37:1-74.

7. De Ley, J. 1965. DNA base composition of Klebsiella rubiacearum. Antonie van Leeuwenhoek J. Microbiol. Serol. 31:203-204.

8. De Vries, J. T., and H. G. Derx. 1953. On the occurrence of Mycoplana rubra and its identity with Protaminobacter rubrum. Ann. Bogor. 1:53-60.

9. Georgevitch, P. 1916. A new case of symbiosis between a bacillus and a plant (Preliminary Note). Bull. Roy. Bot. Gard. Kew. 1916(4): 105-106.

10. Hanada, K. 1954. Über die Blattknoten der Ardisia-Arten. Isolierung der Bakterien und ihre stickstoffbindende Kraft in Reinkultur. Jap. J. Bot. 14:235-268.

11. Horner, H. T., Jr., and N. R. Lersten. 1968. Development, structure and function of secretory trichomes in Psychotria bacteriophila (Rubiaceae). Amer. J. Bot. 55: 1089-1099.

12. Kern, H. 1968. Beiträge zur Taxonomie der Rhizobiaceae. Arch. Mikrobiol. 63:278-291.

13. Knösel, D. 1962. Prüfung von Bakterien auf Fähigkeit zur Sternbildung. Zentralbl. Bakteriol. Parasitenk. Infektionskr. Hyg. Abt. 2 116:79-100. 
14. Lange, R. T. 1966. Bacterial symbiosis with plants, p. 99-1 70. In S. M. Henry (ed.), Symbiosis, vol. 1. Academic Press Inc., New York.

15. Lersten, N. R., and H. T. Horner, Jr. 1967. Development and structure of bacterial leaf nodules in Psychotria bacteriophila Val. (Rubiaceae). J. Bacteriol. 94:2027-2036.

16. Mahl, M. C., P. W. Wilson, M. A. Fife, and W. H. Ewing. 1965. Nitrogen fixaton by members of the tribe Klebsielleae. J. Bacteriol. 89:1482-1487.

17. Miehe, H. 1911. Die Bakterienknoten an den Blatträndern der Ardisia crispa A. DC. Javanische Studien V. Abh. Math. Phys. K1. Sächs. Gesellsch. Wiss. (Leipzig) 32:399-431.

18. Miehe, H. 1913. Weitere Untersuchungen über die Bakteriensymbiose bei Ardisia crispa. I. Die Mikroorganismen. Jahrb. Wiss. Bot. 53:1-54.

19. Miehe, H. 1916. Über die Knospensymbiose bei Ardisia crispa. Ber. Deut. Bot. Ges. 34:576-580.

20. Miehe, H. 1919. Weitere Untersuchungen über die Bakteriensymbiose bei Ardisia crispa. II. Die pflanze ohne Bakterien. Jahrb. Wiss. Bot. 58:29-65.

21. Ouellette, C. A., R. H. Burris, and P. W. Wilson. 1969. Deoxyribonucleic acid base composition of species of Klebsiella, Azotobacter and Bacillus. Antonie van Leeuwenhoek J. Microbiol. Serol. 35:275-286.
22. Rao, K. A. 1923. A preliminary account of symbiotic nitrogen fixation in non-leguminous plants with special reference to Chomelia asiatica. Agr. J. India 18:132-143.

23. Schaede, R. 1939. Die Bakteriensymbiose von Dioscorea macroura. Jahrb. Wiss. Bot. 88: 1-21.

24. Sen, A., and N. B. Paul. 1958. Occurrence of phosphobacterium in the glands of Cassia occidentalis. Indian J. Agr. Sci. 28:21-29.

25. Silver, W. S., Y. M. Centifanto, and D. J. D. Nicholas. 1963. Nitrogen fixation by the leaf-nodule endophyte of Psychotria bacteriophila. Nature (London) 199:396-397.

26. von Faber, F. C. 1912. Das erbliche Zusammenleben von Bakterien und tropischen Pflanzen. Jahrb. Wiss. Bot. 51:285-375.

27. von Faber, F. C. 1914. Die Bakteriensymbiose der Rubiaceen. Jahrb. Wiss. Bot. 54:243-264.

28. Whitmoyer, R. E., and H. T. Horner, Jr. 1970. Developmental aspects of bacterial leaf nodules in Psychotria bacteriophila Val. (Rubiaceae). Bot. Gaz. (Chicago) 131:193-200.

29. Ziegler, H. 1958. Elektronenmikroskopische Untersuchung von symbiontischen Bakterien aus höheren Pflanzen. Z. Naturforsch. 13:297-301.

30. Zimmermann, A. 1902 . Ueber Bakterienknoten in den Blättern einiger Rubiaceen. Jahrb. Wiss. Bot. 37: 1-11. 